\title{
A História literária do Rio Grande do Sul, de João Pinto da Silva
}

\author{
Regina Zilberman ${ }^{1}$
}

João Pinto da Silva (1889-1950) publicou a História literária do Rio Grande do Sul em 1924, reeditada, com acréscimos em 1930. Naquela década, a História da Literatura Brasileira era um gênero ainda em formação. No ano anterior ao que o crítico gaúcho nascera, o sergipano Sílvio Romero (1851-1914) lançara a primeira edição de sua História da literatura brasileira, cuja versão final aparece em 1902. Data de 1916 a História da literatura brasileira, de José Veríssimo (1857-1916), sendo que, no intervalo, registram-se apenas os projetos escolares de Coelho Neto (1864-1934), Compêndio de literatura brasileira, e, de novo, de Sílvio Romero, agora em parceria com João Ribeiro (1860-1934), o igualmente denominado Compêndio de literatura brasileira. Cronologicamente mais próxima do livro de João Pinto da Silva é a Pequena história da literatura brasileira, de Ronald de Carvalho (1893-1935), também em certa medida dirigida ao mercado estudantil, então em ascensão.

As balizas temporais parecem indicar o pioneirismo da iniciativa do escritor gaúcho, até porque as histórias regionais da literatura eram ainda mais raras. Outras peculiaridades do livro decorrem, de uma parte, da circunstância de a obra não ter em vista o público escolar, de outra, do fato de ter sido necessário providenciar a segunda edição em menos de seis anos, sugerindo o relativo sucesso alcançado pelo autor. Desde então, a História literária saiu dos catálogos das editoras nacionais, retornando apenas em 2013, por iniciativa do Instituto Estadual do Livro (IEL) e da Companhia Rio-grandense de Artes Gráficas (CORAG).

Quando a História literária do Rio Grande do Sul apareceu em 1924, João Pinto da Silva era já um intelectual e poeta atuante. Estreara em 1910 com Estalactites, livro de teor simbolista, como faziam os conterrâneos Marcelo Gama (1878-1915), Alceu Wamosy (1895-1923) e Eduardo Guimaraens (1892-1928). Inaugurara a carreira de crítico com Vultos do meu caminho, de 1918, impresso pela Globo, a que se seguiu Fisionomia de novos, de 1922, editado pela então ascendente Monteiro Lobato \& Cia., de São Paulo. Entre as duas edições da História literária, João Pinto desdobrou Vultos do meu caminho em dois volumes, acrescentando novos artigos.

Vultos do meu caminho e Fisionomia de novos, elaborados à época da História literária, revelam a abrangência das leituras de João Pinto, que examina obras de europeus, como Émile Verhaeren (1855-1916), hispano-americanos, como José Enrique Rodó (1872-1917), brasileiros menos ou mais recentes como Cruz e Souza (1861-1898) e Euclides da Cunha (1866-1909), e sul-riograndenses como Fontoura Xavier (1856-1922) e Zeferino Brasil (1870-1942), estes no capítulo "Os quatro melhores poetas modernos do Rio Grande do Sul". O título desse artigo sugere de antemão que a antena de João Pinto captava as correntes artísticas em vigência nas primeiras décadas do século XX, em especial as que explodiam nos anos 1920, no Brasil. Fisionomia de novos inclui, por exemplo, o capítulo "Escola paulista?", destacando o que ocorria na Pauliceia literária daquele período. $\mathrm{Na}$ edição de 1926 de Vultos do meu caminho, "A poesia nova e o Rio Grande" examina os modernistas Felipe d'Oliveira (1890-1932), que acabara de lançar seu programático Lanterna Verde, ao lado da de Augusto Meyer (1902-1970), Raul Bopp (1898-1984) e Vargas

1 Universidade Federal do Rio Grande do Sul. 


\section{Conexão Letras}

Netto (1903-1977).

João Pinto da Silva, portanto, não poderia ter ficado tanto tempo longe das estantes das livrarias e bibliotecas atualizadas, e tão perto dos sebos e lojas de livros usados. A reedição da História literária, acompanhada de estudo introdutório e notas, fazia-se necessária e devemos saudá-la pela oportunidade e relevância.

Cabe frisar que seus méritos não decorrem apenas do pioneirismo de que se reveste. Vale destacá-los, a começar pelo aspecto em que se vem insistindo: a modernidade do pensamento do autor, já que, iniciando a narrativa pelos primeiros passos da literatura local, procura chegar aos poetas e ficcionistas atuantes à época de redação da História literária, como os simbolistas citados e os regionalistas João Simões Lopes Neto (1865-1916) e Alcides Maya (1878-1944). Esse pendor do livro fica acentuado na edição atualizada, que inclui ensaios relativos a escritores do Rio Grande do Sul, extraídos de Vultos do meu caminho e de Fisionomia de novos, que complementariam a História literária original.

Importante também é o foco metodológico adotado, já que o autor não negligencia as relações entre a história e a literatura. Este relacionamento não deveria surpreender, pois Sílvio Romero já o empregara em sua História da literatura. Mas João Pinto, ainda que conheça as manhas do Naturalismo e do Positivismo que embasam a pesquisa do crítico sergipano, e em voga desde meados do século XIX, não incorpora a perspectiva determinista que toma a arte como reflexo do meio, ao qual se submete docilmente. O estudioso gaúcho prefere antes estabelecer as conexões entre os acontecimentos políticos (revolução de 35, abolição, republicanismo) e a produção literária, como maneira de entender por que certos temas se destacam ou o que causa avanços e recuos no âmbito da circulação de obras. Sob esse aspecto, aproxima-se da Sociologia, sem deixar, porém, de enfatizar o ângulo artístico - o fator estético, como denomina - com que observa a prosa e os versos dos escritores sulinos.

Eis o terceiro fator que distingue e valoriza a História literária de João Pinto da Silva. Seu intento não é extensivo, já que não visa esgotar o registro das obras e autores que pertenceriam à literatura do Rio Grande do Sul. Não se limita à poesia, à ficção e ao teatro, incluindo jornalistas e historiadores; ainda assim, consciente de que a historiografia literária é necessariamente seletiva, não se preocupa em inventariar todo e qualquer escritor que tenha atuado na então Província e, depois, Estado. Essa tarefa será desempenhada, igualmente com qualidade, por Guilhermino Cesar (1908-1993), na História da literatura do Rio Grande do Sul, de 1956. No livro de João Pinto, o objetivo é estrutural e interpretativo, buscando examinar os componentes de um texto, bem como seu significado enquanto expressão verbal. O historiador abre espaço ao crítico, que se apresenta enquanto leitor qualificado de um passado e de uma trajetória. Também por esse ângulo o resultado alcançado é moderno e atual.

Com quase cem anos de existência, a História literária do Rio Grande do Sul dialoga com o presente com toda a vitalidade de que sempre foi capaz.

João Pinto da Silva. História literária do Rio Grande do Sul. Porto Alegre: CORAG; Instituto Estadual do Livro, 2013. 